\title{
Adriatic Wine Amphorae in Nea Paphos
}

\author{
MARTA BAJTLER
}

\begin{abstract}
The aim of this study is to present data on the amphorae and stoppers of Adriatic production coming from Cyprus, in particular from Nea Paphos. Three kinds of wine amphorae, Greco-Italic, Lamboglia 2 and Dressel 6A, closely related to each other due to a common element - a ceramic disk, which they were sealed with - appear in small amounts on sites from the late Hellenistic to the early Roman period. They are also attested at Maloutena in Nea Paphos. Analysis of these imports was carried out in order to define the quantity and variety of the material. The preliminary results were incorporated into the present paper.
\end{abstract}

Keywords: Adriatic amphorae, amphora stoppers, Nea Paphos, Cyprus

Marta Bajtler, Institute of Mediterranean and Oriental Cultures, Polish Academy of Sciences, Warsaw; mbajtler@iksio.pan.pl; (10)0000-0003-0127-0590

This paper is the first attempt to present the Adriatic wine amphorae and stoppers discovered during the research of the Polish Archaeological Mission of the University of Warsaw at Nea Paphos, and to collect data on comparable finds from other sites on Cyprus. Preliminary research on discussed assemblage were conducted in the 2018 season. They aimed at identifying the quantity, variety and state of preservation of the material collected during previous fieldworks. The finds from 1985-1995 and 2016 were included in the analysis. ${ }^{1}$ The artefacts came from various contexts within the 'Hellenistic' House, Villa of Theseus and House of Aion.

The 'Hellenistic' House, in fact built at an early Roman-era date (late first and early second century $\mathrm{AD}$ ), ${ }^{2}$ was destroyed in the second century $\mathrm{AD}$ (as a result of the earthquake

\footnotetext{
${ }^{1}$ The material from different seasons shows a huge difference in the form of documentation, what is also reflected in the variety and quantity of the stored finds.

${ }^{2}$ In the light of recent research, the residence is dated to early Roman period (Meyza et al. 2017). Initially this residence was dated to Hellenistic period, and hence the name. For dating, see also: Papuci-Władyka, Miszk 2020: 96.
} 
most probably from Hadrian's time), and the Villa of Theseus was erected on part of its ruins. ${ }^{3}$ The multi-phase villa in the fourth century AD became the largest residential complex known so far from Roman Cyprus. The residence was used until the fifth century AD. ${ }^{4}$ The last above-mentioned complex was the late Roman House of Aion, located to the east of the Villa of Theseus, and dated between the mid-fourth and fifth centuries AD. ${ }^{5}$

\section{ADRIATIC WINE AMPHORAE AND STOPPERS}

The general aim of the paper is analysis of some selected, closely related in terms of form and development types of amphorae and stoppers from among all available Adriatic pottery. ${ }^{6}$ These are the Greco-Italic, Lamboglia 2, and Dressel 6A wine amphorae, and some related transitional types. ${ }^{7}$ All of them were sealed by ceramic stoppers in a form of a disk with a centrally placed knob. ${ }^{8}$ Adriatic stoppers reflected a very uniform craft tradition in the method of hermetically sealing the amphorae. ${ }^{9}$

Kiln and workshop sites, where the described above amphorae and stoppers were produced, are known from the Italian coast. ${ }^{10}$ According to some scholars, these vessels could have been produced also in central Dalmatia, in the areas where the Greek settlements appeared early (islands Vis/Issa and Hvar/Pharos). ${ }^{11}$ The lack of pottery-workshop sites of this type of amphorae on the eastern coast of the Adriatic does not necessarily indicate that these vessels were not produced there. ${ }^{12}$

3 Meyza 2010: 37.

4 Papuci-Władyka, Miszk 2020: 95.

5 Brzozowska-Jawornicka 2019: 89; Papuci-Władyka, Miszk 2020: 97.

${ }^{6}$ In amphorae produced in the Adriatic Sea region one can also include other types of transport containers that will not be discussed in the present paper. These are among others flat bottomed amphorae (Forlimpopoli), Dressel 2-4, ovoid amphorae, Dressel 6B or anfore collo ad imbuto (Cipriano, Mazzocchin 2017) on the western coast, and on the eastern one, in the region of Dalmatia Cirkvenica, flat bottomed amphorae (Lipovac Vrkljan 2011). On Adriatic amphorae, see also: Carre, Monsieur, Pesavento Mattioli 2014; Carre, Pesavento Mattioli 2003a; 2003b; Cipriano, Mazzocchin 2017; 2018; 2019; Manacorda, Pallecchi 2012; Maritan, Mazzoli, Mazzocchin 2019; Pesavento Mattioli, Carre 2009; Toniolo 2000.

7 Amphorae of transitional types are known from both sides of Adriatic Sea, e.g. amphorae Greco-Italic/ Lamboglia 2 are attested on shipwreck near islet Saplun, Croatia (Radić 2003: 158) and in workshop of Acquabona near Potenza Picena, Italy (Carre, Monsieur, Pesavento Mattioli 2014: 421), while amphorae Lamboglia 2/ Dressel 6A were found in Fosso F. Biago, Fermo (Cipriano, Mazzocchin 2017: 37).

8 For a general, although not completely up-to-date, overview of ceramic stoppers to Adriatic amphora, see: Bajtler 2015: 76-79.

9 Lindhagen 2020: 343.

10 Bezeczky 2019; Carre, Monsieur, Pesavento Mattioli 2014; Lindhagen 2009; Van Limbergen 2018 : $202-212$.

11 Cambi 1989; Carre, Monsieur, Pesavento Mattioli 2014: 427; Kirgin, Katunarić, Šešelj 2005: 13; Lindhagen 2009; 2020.

12 Agatharchides (second century BC) wrote about excellent wine from Issa (Lindhagen 2009: 92), and Strabo (64 BC-AD 21) described the Dalmatian islands as rich in wine as olives (Strabo., Geog. VII.5.10). Another region where such a cultivation could take place is the valley of the Neretva River that cuts deep into the land and reaches an important commercial emporium Narona (from first century BC known as Roman colony Colonia Iulia Narona) (Lindhagen 2009: 94). The river in antiquity was navigable and, according to Pseudo-Scylax (mid-fourth 
All these types of amphorae were made of so-called Adriatic fabric. In general, it was characterised by pale light yellow through light brown to light pink colour, often a soft surface with red-brown inclusions and an admixture of silver or gold mica, limestone and sand. ${ }^{13}$ The Adriatic fabric shows some differences between production centres. In some cases, it was possible to observe large red lumps and smears, which are an element of the matrix and the result of the presence of terra ross $a,{ }^{14}$ while others were pale with very fine admixture and almost no red inclusions.

On the Adriatic coast, Greco-Italic amphorae were produced from c. $300 \mathrm{BC}$ until $125 \mathrm{BC} .{ }^{15}$ The earliest attested finds from Italian workshops belonged to the late Greco-Italic form, confirmed in at least seven workshops. ${ }^{16}$ These amphorae were characterised by a triangular rim and a more elongated shape compared to earlier variants. The Lamboglia 2 amphorae, which in the Adriatic area were produced c. $125-25 \mathrm{BC},{ }^{17}$ evolved directly from late GrecoItalic form. It was characterised by a bag-shaped body with maximum diameter in the lower part and carination on the lower part of the shoulders, thick walls, a long cylindrical neck with a characteristic triangular to square rim, massive oval-shaped handles and a distinct, short foot. The main production area is the central and northern part of the western coast of the Adriatic (Veneto, Marche, Abruzzo) and Apulia in the south. ${ }^{18}$ The Lamboglia 2 type was replaced by the Dressel 6A amphorae, which directly evolved from the previous form. It was a more massive and larger container with a pear-shaped body, a massive square rim, round handles and a long, distinct foot. This type of amphora was produced in Middle Adriatic and Picenum area, ${ }^{19}$ from c. 25 BC until c. AD 25/50. ${ }^{20}$

century BC), 'trier and merchant vessels enter it' (Ps. Skylax 24). If the grapevine grew there, traders and buyers had no problems transporting local wine. Important find came from shipwreck Stori Stoni where more than one hundred amphorae Lamboglia 2 were found all without their stoppers, which were found in separate locations. This shipwreck was found near Hvar, on the route from ancient Issa to Narona (Royal 2012: 429).

${ }_{13}$ Lindhagen 2009: 86.

${ }^{14}$ Presence of terra rossa was confirmed at Istria and it was used in production of Istrian amphorae from Fažana workshop: Bezeczky et al. 2019: cat. nos 9-22; Szakmány, Józsa 2019: 189; Szakmány et al. 2020. Lindhagen presented a very characteristic fabric of two bad mixed clays (red and yellow) from Greco-Italic amphora found at Ošanići, Bosnia and Herzegovina (Lindhagen 2020: Fig. 1). A very similar fabric was described by Verena Gassner, as coming from Southern Illyria (Apollonia?) and/or the Apulian Coast (Gassner 2011: 4). For other archaeometric analysis on Adriatic amphorae, see: Daszkiewicz et al. 2007; Machut et al. 2015; Maritan, Mazzoli, Mazzocchin 2019; Menchelli et al. 2008; Sondi, Slovenec 2003; Zupančič, Horvat, Bole 1998.

${ }^{15}$ Forms similar to MGS V and VI (Panella 2010: 13; Lindhagen 2020: 344). These abbreviations refer to typology proposed by Christian Vandermersch, dividing the Greco-Italic amphorae into the types MGS I-VI (Magna Graecia and Sicily I-VI) (Vandermersch 1994). Form MGS V roughly corresponds with Daniele Manacorda Greco-italica antica and form MGS VI is similar to Manacorda Greco-italica tarda (Van Limbergen 2018: 205).

${ }^{16}$ Van Limbergen 2018: 205-206. Greco-Italic amphorae were probably produced also on the island Vis/ Issa (Lindhagen 2020).

${ }^{17}$ Van Limbergen 2018: 206.

${ }^{18}$ Carre, Monsieur, Pesavento Mattioli 2014: 419-422; Van Limbergen 2018: 207-208.

${ }^{19}$ Carre, Monsieur, Pesavento Mattioli 2014: 422-223; Cipriano, Mazzocchin 2019: 235; Maritan, Mazzoli, Mazzocchin 2019: 207. The possibility of Northern-Italic origin is also discussed, but this hypothesis is mainly based on inscriptions from amphorae (Maritan, Mazzoli, Mazzocchin 2019).

${ }^{20}$ Van Limbergen 2018: 210. 
Ceramic stoppers were made of the same fabric as the above-mentioned amphorae and were always of a similar size. Most of them took the form of disks about 9-10 cm in diameter and $1-2 \mathrm{~cm}$ in thickness. They were produced on a potter's wheel or pressed out of a one- or two-pieces mould. As potters did not pay a lot of attention to the production of stoppers, some of them were not moulded properly and had finger dents or fingerprints on the surface. ${ }^{21}$ Mould-made stoppers had also decorations or inscriptions. Decorations consisted mostly of geometric and linear motives. Sometimes rosettes, solar motives, anchors or animal figures also are attested. Inscriptions were mostly in Latin, but some also in Greek. The most common were single letters but sporadically entire names are attested. ${ }^{22}$ With the current state of knowledge, it is impossible to match a specific stopper to a given type of amphora.

\section{RESULTS}

The present study, as mentioned above, includes material from seasons 1985-1995 and 2016. A total number of seventy-six amphorae and stoppers' fragments were documented, including those discussed in detail in the present paper (see below, Catalogue) - six stoppers and twenty-five amphorae diagnostic elements (one stamped amphorae). The Villa of Theseus yielded in total thirteen fragments, while from the 'Hellenistic' House were fifty-three fragments and from the House of Aion ten. Most of the studied material came from the 'Hellenistic' House, mainly from the 2016 season (forty-one fragments), when a circular pool with amphorae Dressel 6A used as an element of its construction was found. ${ }^{23}$

\section{FABRIC}

The fabric of the studied fragments generally corresponds well to Adriatic fabric. The surface is soft, and in some cases it flaked when rubbed. The fabric is usually light yellow-brown, light orange or slightly pinkish in colour. In the case of light yellow examples, a light pink core is attested. A very characteristic feature was the presence of red-brown inclusions of iron oxides (small, dark brown particles) and large, red fractions, often turning into smears, which were part of the matrix of terra rossa. The admixture was generally well sorted, fine and usually sparse. Quartz (sand), silver mica (rarely gold), limestone and black small inclusions appeared most often. Some variations in the fabric among the fragments were observed, which probably reflect different production centres in the Adriatic region. ${ }^{24}$

21 Bajtler 2013: 77.

22 Bajtler 2015: 74.

${ }^{23}$ Romaniuk 2017.

${ }^{24}$ Based on petrographic analyses, Bezeczky characterised several basic types of fabrics found in Adriatic products. For description of fabric and photos of Lamboglia 2 amphorae found in Ephesus, see: Bezeczky 2013: 117-118, Pls 75-76, 89, 96, 99; for Dressel 6A amphorae, found in Ephesus, see: Bezeczky 2013: 123, Pls 76, 89, 94, 96, 99-100; for Dressel 6B amphorae, from Fažana workshop, see: Bezeczky et al. 2019: 


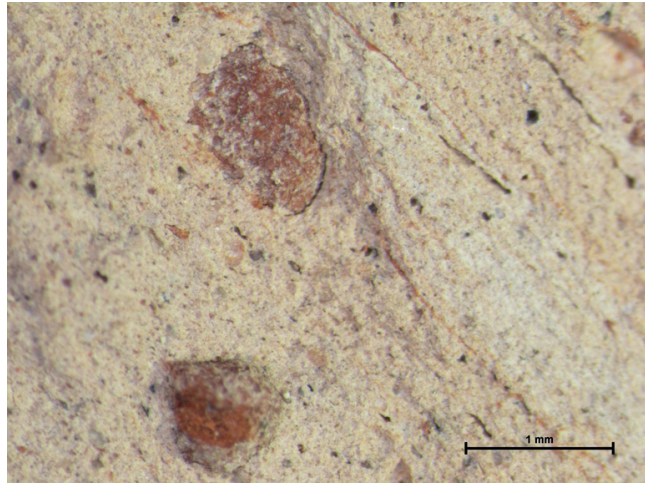

1. Fabric of Lamboglia 2 amphora (Phot. M. Bajtler).

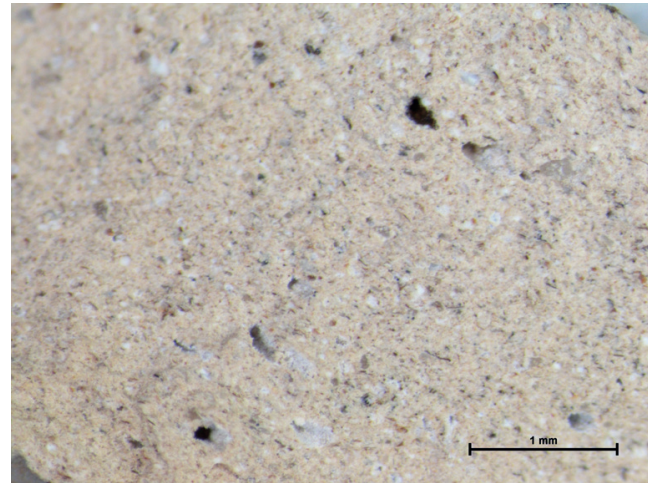

2. Fabric of Dressel 6 A amphora (Phot. M. Bajtler).

The terra rossa was found in case of four specimens of Dressel 6A and in the majority of Lamboglia 2 examples, which yielded even smears (Fig. 1). Most of the Dressel 6A fragments, however, was produced in a light, dusty fabric with few admixtures (Fig. 2).

\section{AMPHORAE}

The earliest form that was identified in the presented set is the late type of Greco-Italic amphorae (cat. nos 1-2; see below, Catalogue and Fig. 4), although it cannot be ruled out that these were fragments of early Lamboglia 2 amphorae. Both examples are fragmentarily preserved rims. Their triangular in cross-section rim was traditionally ascribed to the Greco-Italic forms, but the transitional types and the early Lamboglia 2 forms also had such a shape of rim.

Seven fragments (cat. nos 3-9; see below Figs 4-5), including six rims and one handle fragment, were identified as representing the classic form of Lamboglia 2. Two rims were slender and slightly triangular in cross-section, which could indicate that they belonged to earlier variants (cat. nos 3,5). The remaining four specimens were massive and square in cross-section (cat. nos 4, 6-7, 9). The only fragment which does not preserve a rim was assigned to this group on the basis of the shape of the handle: slender and oval in cross-section (cat. no. 8).

Among the analysed amphorae, the Dressel 6A type was the most numerous. A total of thirteen fragments were identified (cat. nos 10-22; see below Figs 5-7), including two with at least two distinctive features, six rims, three handles and two foots. The Dressel 6A

Pls 18-19; Szakmány, Józsa 2019; for stoppers found in Ephesus, see: Bezeczky 2013: 148, 148, Pls 80-81. The presence of terra rossa as part of the matrix was confirmed for amphorae produced in Istria (ante Dressel 6B and Dressel 6B). Products in a light, smooth and delicate fabric with a small admixture probably came from northern Italy. For the western Adriatic coast clays with numerous fine admixtures and the presence of microfossils were defined (Bezeczky 2013: 117-118). 
amphorae presented a large range of variants. Three rims, massive and square in crosssection, are closely associated with Lamboglia 2 and could have belonged to the early forms of Dressel 6A (cat. nos 10, 12, 18). The remaining rims were elongated, some even slightly semicircular and glued to the neck (cat. nos 13-14, 16-17, 20). Almost all documented handles were preserved in fragments. They were characterised by a round or almost round cross-section and a massive structure (cat. nos 11, 13, 16, 19, 21). Both foots (cat. nos 15, 22) were massive, and one was almost completely preserved. An unusual variant was the amphora cat. no. 16. Almost the entire its upper part was preserved and it clearly reflect characteristics of the Dressel 6A type. However, it was smaller than the classic examples and the walls were very thick, on average $5 \mathrm{~mm}$ thicker than in other examples.

Three handle fragments (cat. nos 29-31; see below Fig. 8) were defined as Adriatic forms only on the basis of the fabric, since they were too small to be classified typologically.

\section{AMPHORAE STOPPERS}

A total of six amphorae stoppers were documented (cat. nos 23-28; see below Figs 7-8). Three of them were complete and the other three approximately half-preserved. All stoppers were produced in a one-piece mould. They were characterised by the shape of a flat disk with a centrally placed knob (preserved only on cat. nos 24-25, 28). On two stoppers there were traces of decorations and probably signs/letters. The linear motif, present on the stopper cat. no. 24, was a simple decoration consisting of four lines radiating at regular intervals from the knob. The signs/letters marked on cat. no. 25 are, unfortunately, illegible since the stopper is only half-preserved.

\section{DISCUSSION}

Compared to the finds of other amphorae from the same site, the Adriatic amphorae and the accompanying stoppers are not numerous. This observation relates not only to Nea Paphos itself, but also throughout Cyprus. Due to the manner of publication and discrepancy between different, sometimes outdated, applied classification system, ${ }^{25}$ identification of particular amphora as representing one of the above-mentioned types is often difficult.

The largest number of Adriatic amphorae on Cyprus was discovered in Nea Paphos. In addition to the specimens presented here in detail from the 'Hellenistic' House, the Villa of Theseus and the House of Aion, such amphorae were documented on agora, in the

${ }^{25}$ For example, the type Dressel 6 is applied in several publications, which describes the amphorae of the Adriatic provenance (among others: Connelly 2010; Hayes 1991: 88). It was defined by Henrich Dressel in the late nineteenth century, who was not able to distinguish between the Dressel 6A and Dressel 6B types and perceived them as one (Dressel 1899: Table II; Bezeczky 2013: 122). Another typological inaccuracy is the use of an out-of-date Peacock and Williams typology (Peacock, Williams 1986) which describes the Lamboglia 2, Dressel 6A and Dressel 6B amphorae collectively as Class 8 (A-B forms) and defines their origin as Istrian (Hayes 1991: 88; Kaldeli 2008: 112; Peacock Williams 1986: 98-101). 
House of Dionysos, from the House of Orpheus, Saranda Kolones and outside the Nea Paphos, in Amathus and in Cypriot coastal waters (Table 1).

The largest collection of Adriatic amphorae fragments of Dressel 6A type comes from the House of Dionysos, ${ }^{26}$ the vast majority from a deposit dated 1-15/20 AD. ${ }^{27}$ Some Dressel 6A fragments and stoppers ${ }^{28}$ were collected also in various other deposits throughout the house (e.g. in the Fish-tank dated to early first century AD). ${ }^{29}$ From the House of Dionysos, in total, John W. Hayes listed more than 160 fragments of amphorae and stoppers of Adriatic origin. ${ }^{30}$ Subsequent finds were much less numerous. A set of eighteen fragments was documented from the agora of the Nea Paphos, ${ }^{31}$ including sixteen referred to as Lamboglia 2 or Dressel 6A. These were found in late Hellenistic and early Roman contexts. ${ }^{32}$ Another, similarly numerous, collection came from the 'Hellenistic' House. It consisted of twentytwo fragments of amphorae and stoppers. ${ }^{33}$ From the Villa of Theseus, thirteen fragments of different types of amphorae were identified, ${ }^{34}$ and seven from the House of Aion. ${ }^{35}$ Few Adriatic amphorae fragments are known from the Saranda Kolones (four amphorae fragments and one stopper) ${ }^{36}$ and from the House of Orpheus (three fragments). ${ }^{37}$

Outside the Nea Paphos, the Adriatic amphorae are even more sporadic. Anthi Kaldeli mentions Istrian Class 8 amphorae from Amathus, specifically from agora and Palea Lemesos ${ }^{38}$ as well as Dressel 6A fragments from agora. ${ }^{39}$ An underwater find of an intact amphora, now in the Larnaca District Museum, is known from Cape Greco. Although, it was described in the publication as Dressel 6, it is most probably a Middle-Adriatic ovoid olive oil amphora. ${ }^{40}$ The most interesting find is the Kiti N1 shipwreck, discovered off the coast of Cape Kiti. The shipwreck contained a cargo of amphorae of Adriatic production. Thirty-two fragments of Dressel 6A amphorae and three stoppers were identified, one

${ }^{26}$ House of Dionysos was built at the end of second century AD and abandoned in third century AD (PapuciWładyka, Miszk 2020: 94).

${ }^{27}$ Hayes 1991: 180.

${ }^{28}$ Term 'stopper' was also applied to a very different type of artefact, which were small vases (Hayes 1991: 74).

${ }^{29}$ Hayes 1991: 199.

${ }^{30}$ Hayes 1991: 88, Fig. 39:1-3, Pl. 22:7, 11-12; 186, nos 74-77, Pl. 22:6; 199, Pl. 23:1-11.

${ }_{31}^{31}$ For more information about excavations at agora, see: Papuci-Władyka 2020a.

32 Dobosz 2020: 345.

${ }^{33}$ For material not presented in this paper, see: Meyza, Bagińska 2013: 137; Meyza et al. 2017: 423, Fig. 24.1-3; Sztetyłł 2010: no. 187.

${ }^{34}$ For material not presented in this paper, see: Meyza, Bagińska 2013: 137; Sztetyłło 1991: 101, nos 246, 247.

${ }_{35}$ For material not presented in this paper, see: Meyza, Bagińska 2013: 137.

${ }^{36}$ Hayes 2003: 464, inv. no. 4091/21; 470, inv. no. 115, Fig. 9; 472, inv. nos 140-141, Fig. 14; 477-478, inv. no. 172. Saranda Kolones is a thirteenth-century fortress that was built in an area with ancient pottery deposits (Hayes 2003: 449).

${ }^{37}$ Demesticha 2015: 64. House of Orpheus is a Roman residence dated to the end of the second and early third century AD (Kaldeli 2009: 370).

${ }^{38}$ Kaldeli 2008: 115-116.

39 Demesticha 2015: 64.

${ }^{40}$ Connelly 2010: 190; for analogies, see: Cipriano 2009: Fig. 7. 


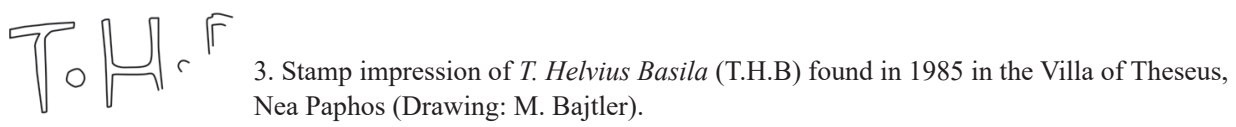

of which was recorded still in situ, in the container's neck. ${ }^{41}$ Most probably an another complete amphora of the same type discovered during earlier archaeological investigations in the very same area also belonged to this cargo. ${ }^{42}$

Stamp impressions were noted on twelve Adriatic amphorae from Cyprus, all of Dressel 6A type. The most numerous type of stamp impressions was with inscription T.H.B (Fig. 3), which appeared on as many as nine specimens. This was an abbreviation of T. Helvius Basila, a legate of Tiberius and Claudius, possibly an owner of property in Calabria. ${ }^{43}$ This type of stamp impression was widely distributed in Rome and the Cisalpine region, as well as in Greek and African areas. ${ }^{44}$ On Cyprus, amphorae fragments with such impressions were found in the Villa of Theseus and in 'Hellenistic' House (three specimens in each case), in the House of Dionysos (two specimens) and in the Kiti N1 shipwreck (one specimen).

Two more stamped amphorae fragments were found in the House of Dionysos, both probably with the same inscription SAFINIAEPICE. ${ }^{45}$ These stamps represented Safinia Picens/Picentina and it is possible that the Dressel 6A amphorae stamped this way were produced at Picenum. Outside Italy, besides two fragments from House of Dionysos, they are attested only in Carthage. ${ }^{46}$

The last kind of stamp impression on Adriatic amphora from Cyprus belonged to P.HER.PHAE, and was discovered in the Saranda Kolones. Only a drawing of it was published, ${ }^{47}$ therefore it was impossible to verify if it was correctly read. It is probably associated with an another individual attested on stamps, M.HER.PHAE, a member of the Herennii family - M. Herennius Phaedimus. Herennia stamps appeared in various variants on Dressel 6A amphorae, which were found in great numbers in northern Italy. The place of their production has so far not been confirmed, but possibly this was Picenum. ${ }^{48}$

Most of the Adriatic pottery from Nea Paphos was found in a secondary context, not reflecting the actual date of this material. The only part of the site, as far as the present author is aware, where Adriatic amphorae were recorded in their original context is agora. Lamboglia 2/Dressel 6A were found during archaeological works there in the third

\footnotetext{
41 Demesticha 2015: 63-64, Table 3.

42 Demesticha 2015: 64, Fig. 5.2-5.3; Engvig, Beichmann 1984: 181-182, Fig. 16.

43 Bezeczky 2013: 120, 122.

44 Toniolo 1991: 187.

45 One of them, according to the present author analysis of available photo, was misread.

46 Van Limbergen 2018: 211.

47 Hayes 2003: 470, no. 115, Fig. 9.

48 More about gens Herennia: Cipriano 2016: 148-150.
} 
phase of amphorae circulation, i.e. from the end of second century to the end of the first century BC. ${ }^{49}$ Generally, the periodisation system adopted for the Paphos Agora Project reflects changes in the types of Adriatic amphorae: the late Hellenistic period (late second century until c. $30 \mathrm{BC}$ ) corresponds to dating of late Greco-Italic and Lamboglia 2 types and early Roman I period (27 $\mathrm{BC}-\mathrm{AD} 68)$ fits well to the dating of Dressel 6A. ${ }^{50}$

Most of the finds from other parts of the site came from secondary archaeological contexts. The 'Hellenistic' House, the Villa of Theseus and the House of Aion - hence the find spot of the material studied here - are later than the analysed Adriatic amphorae. Therefore, the fragments of Adriatic amphorae must have been associated with earlier constructions. ${ }^{51}$ The Maloutena Adriatic amphorae were often used as construction material (hence the fragments often show traces of mortar), e.g. for a pool ${ }^{52}$ or in various earth fillings. Some Adriatic amphorae and stoppers were found in sealed deposits, sometimes very precisely dated, such as those from the House of Dionysos with material from the beginning of the first century century AD. ${ }^{53}$ Other deposits, in contrast, contained material very broadly dated, as in the case of deposits 3 and 4 of the Saranda Kolones dated to the second century $\mathrm{BC}-$ first century century $\mathrm{AD} .^{54}$

Compared to other types of imported amphorae of the same age, ${ }^{55}$ Adriatic amphorae are quite rare on Cyprus, including the Nea Paphos. This could indicate that Adriatic wine on Cyprus played a less important role than goods from other parts of the Mediterranean or local products. The island lay on a very important sea route to Egypt, ${ }^{56}$ and the Nea Paphos - strategically located on the west coast - could have been a stopover along the way. Interesting, then, is the presence of the Kiti N1 shipwreck found off the southern coast of Cyprus. As Stella Demesticha points out, this is evidence of an unfortunate accident that drove the ship eastward, ending its voyage on the Cape Kiti reefs, rather than the regular route that Adriatic products were transported. ${ }^{57}$

49 Dobosz 2020: 349. For Paphos Agora Project, Agata Dobosz proposed a periodisation system of amphorae circulation.

50 Papuci-Władyka 2020b: 80, Table 1.

51 For example, from the so-called Early Roman House, dated to the end of the first century century $\mathrm{BC}$ (Papuci-Władyka, Miszk 2020: 96).

52 Meyza et al. 2017: 423-426; Romaniuk 2017.

53 Hayes 1991: 200.

54 Hayes 2003: 448.

55 Dobosz 2020: 325-347; Kaldeli 2008: 112-116.

56 Adriatic wine was exported to Egypt, what is corroborated, e.g. by the QB1 shipwreck, discovered near Fort Qaitbay (Alexandria). It contained mainly a cargo of Adriatic amphorae Lamboglia 2 and Dressel 6A (Boichot 2016; Empereur 1999: 546-547).

57 Demesticha 2015: 70. 


\section{CONCLUSIONS}

Although the issue of Adriatic transport pottery is a recurrent element of publications on amphorae from particular sites on Cyprus, and they are usually discussed in the context of imports from the western part of the Mediterranean basin, amphorae and stoppers of Adriatic production known from the island have never been the subject of individual study. The present research is based only on restricted material, so the conclusions can only be preliminary. The largest amount of Adriatic wine containers on Cyprus was confirmed for Nea Paphos, which, as the capital of Roman Cyprus, had numerous commercial connections with the most important Mediterranean ports. ${ }^{58}$ Nonetheless, Adriatic amphorae, and thus the wine transported in them, did not play a particularly significant role among the imported goods. On the island, especially in Nea Paphos, they seem to appear more due to geography, as this was a strategic location on the sea route to Egypt. They create, however, a visible share of amphorae from the western part of the Mediterranean basin.

The changes in popularity and types of Adriatic wine amphorae could be somehow correlated with political events taking place then on Cyprus. In $58 \mathrm{BC}$ the island was included into the Roman Empire as part of the Cilicia Province. These events coincided with a change in the types of amphorae produced on the Adriatic coast. At some time in the last quarter of first century BC, the Lamboglia 2 amphora was replaced with the Dressel 6A type. The appearance of Nea Paphos in the sphere of direct Roman influence probably caused an inflow of a greater number of Adriatic products. This process could be observed in the increasing number of Adriatic amphorae: while the Greco-Italic type is very rare, the Dressel 6A type is most abundant (Table 1).

Further works on the Adriatic amphorae from Nea Paphos most probably will not bring a drastic change in the general picture of the presence of these containers on the island, but they may provide new data about the specific types of amphorae (and variants of fabrics) imported to Cyprus.

\section{References}

Bajtler, M. 2013: Wstępne studium ceramicznych korków do amfor ze stanowiska Risan w Czarnogórze z lat 2001-2008, Novensia 24, 75-89

Bajtler, M. 2015: Ceramic amphora stoppers from the east coast of the Adriatic, Novensia 26, 69-81

Bezeczky, T. 2013: The amphorae of Roman Ephesus, Forschungen in Ephesos XV/1, Wien

Bezeczky, T. 2019: Italian and Istrian amphorae, [in:] Bezeczky, T. (Ed.), Amphora Research in Castrum Villa on Brijuni Island, Denkschriften der philosophisch-historischen Klasse 509, ArchForsch 29, Wien, 41-46

\footnotetext{
${ }^{58}$ Kaldeli 2008: 130.
} 
Bezeczky, T., Millet, P.B., Bonifay, M., Capelli, C., Cesteros, H.G., Józsa, S., Szakmány, G. 2019: Catalogue, [in:] Bezeczky, T. (Ed.), Amphora Research in Castrum Villa on Brijuni Island, ArchForsch 29, Wien, 79-100

Boichot, N. 2016: The shipwreck QB1 off Qaitbay Fort (Alexandria), Centre d'Études Alexandrines (USR 3134 of CNRS), Final report, https://honorfrostfoundation.org/ wp-content/uploads/2020/03/CEAlex-Qaitbay-QB1Shipwreck-2016.pdf (accessed September 20, 2021)

Brzozowska-Jawornicka, A. 2019: Architecture of the Official Spaces of Selected Residences in Nea Paphos, Cyprus, Światowit LVIII, 87-105

Cambi, N. 1989: Anfore romane in Dalmazia, Publications de l'École Française de Rome $114,311-337$

Carre, M.-B., Monsieur, P., Pesavento Mattioli, S. 2014: Transport amphorae Lamboglia 2 and Dressel 6A: Italy and/or Dalmatia? Some clarifications, JRA 27, 417-428

Carre, M.-B., Pesavento Mattioli, S. 2003a: Anfore e commerci nell'Adriatico, [in:] Lenzi, F. (Ed.), L'Archeologia dell'Adriatico dalla Preistoria al Medioevo. Atti del Convegno Internazionale (Ravenna, 7-8-9 giugno 2001), Bologna, 268-285

Carre, M.-B., Pesavento Mattioli, S. 2003b: Tentativo di classificazione delle anfore olearie Adriatiche, AquilNostr 74, 453-476

Cipriano, S. 2009: Le anfore olearie Dressel 6b, [in:] Pesavento Mattioli, S., Carre, M.-B. (Eds), Olio e pesce in epoca Romana. Produzione e commercio nelle regioni dell'alto Adriatico. Atti del convegno (Padova, 16 febbraio 2007), Antenor Quaderni 15, Roma, 173-189

Cipriano, S. 2016: Anfore Lamboglia 2, Dressel 6A e Dressel 6B dal Piazzale della Cattedrale di Iulia Concordia: nuovi dati, [in:] Buora, M., Magnani S. (Eds), Instrumenta inscripta VI. Le iscrizioni con funzione didascalico-esplicativa. Committente, destinatario, contenuto e descrizione dell'oggetto nell'instrumentum inscriptum. Atti del VI Incontro Instrumenta inscripta, Aquileia, 26-28 Marzo 2015, AAAdr 83, Trieste, $145-158$

Cipriano, S., Mazzocchin, S. 2017: Western Adriatic amphorae productions: the research status, [in:] Lipovac Vrkljan, G., Radić Rossi, I., Konestra, A. (Eds), Adriamphorae. Amphorae as a resource for the reconstruction of economic development in the Adriatic region in Antiquity: local production, Zagreb, 33-47

Cipriano, S., Mazzocchin, S. 2018: Sulla cronologia delle anfore Dressel 6A: novità dai contesti di bonifica della Venetia, $R C R F$ 45, 261-271

Cipriano, S., Mazzocchin, S. 2019: Dressel 6B and Dressel 6A's oil and wine production in North Italy and the Adriatic western coast ( $1^{\text {st }}$ century BC-2 ${ }^{\text {nd }}$ century AD), [in:] Remesal Rodríguez, J., Revilla Calvo, V., Martín-Arroyo Sánchez, D.J., Martín i Oliveras, A. (Eds), Productive landscapes and trade networks in the Roman Empire, Collecció Instrumenta 65, Barcelona, 233-246

Connelly, J.B. 2010: Cyprus in the age of empires: Hellenistic and Roman periods, 310 BC-AD 330, [in:] Hadjiisavvas, S. (Ed.), Cyprus - crossroads of civilizations, Nicosia, 173-195 
Daszkiewicz, M., Dyczek, P., Schneider, G., Bobryk, E. 2007: Preliminary results of archaeometric analysis of amphorae and Gnathia-type pottery from Risan, Montenegro, [in:] Waksman, S.Y. (Ed.), Archaeometric and Archaeological Approaches to Ceramics. Papers presented at EMAC '05, 8th European Meeting on Ancient Ceramics, Lyon 2005, BAR-IS 1691, Oxford, 85-93

Demesticha, S. 2015: Gone with the waves: scattered Roman amphorae in shallow waters around Cape Kiti, Cyprus, [in:] Demesticha, S. (Ed.), Per Terram, Per Mare: Seaborne Trade and the Distribution of Roman Amphorae in the Mediterranean, SIMAP 180, Uppsala, 55-76

Dobosz, A. 2020: Hellenistic and Roman Transport Amphorae, [in:] Papuci-Władyka, E. (Ed.), Interdisciplinary Research of the Jagiellonian University in Nea Paphos UNESCO World Heritage Site (2011-2015): First Results, Paphos Agora Project 1, Cracow, 323-362

Dressel, H. 1899: Inscriptiones urbis Romae latinae. Instrumentum domesticum, CIL 15, 2, 1, Berolini

Empereur, J.-Y. 1999: Alexandrie (Égypte), BCH 123/2, 545-568

Engvig, O.T., Beichmann, M. 1984: Underwater activities and the situation at Cape Kiti, Cyprus, OpAth 15, 181-186

Gassner, V. 2011: Amphorae Production of the Ionic-Adriatic Region, Facem (version 06/06/2011), http://www.facem.at/project-papers.php (accessed September 25, 2021)

Hayes, J.W. 1991: Paphos III. The Hellenistic and Roman pottery, Nicosia

Hayes, J.W. 2003: Hellenistic and Roman Pottery Deposits from the 'Saranda Kolones' Castle Site at Paphos, ABSA 98, 447-516

Kaldeli, A. 2008: Roman amphorae from Cyprus: integrating trade and exchange in the Mediterranean, unpublished $\mathrm{PhD}$ thesis, Institute of Archaeology University College London, London

Kaldeli, A. 2009: Trade and the transmission of Roman values to Cyprus, as evidenced by the amphorae, CCEC 39, 365-386

Kirgin, B., Katunarić, T., Šešelj, L. 2005: Amfore i fina keramika (od 4. do 1. st. pr. Kr.) iz srednje Dalmacije: preliminarni ekonomski i socijalni pokazatelji, Vjesnik za arheologiju i povijest dalmatinsku 98/1, 7-24

Limbergen, D. Van 2018: The Central Adriatic Wine Trade of Italy Revisited, OJA 37/2, 201-226

Lindhagen, A. 2009: The transport amphoras Lamboglia 2 and Dressel 6A: a central Dalmatian origin?, JRA 22, 83-108

Lindhagen, A. 2020: A central Dalmatian origin of the Adriatic wine amphorae? New evidence from xrf-analysis, [in:] Kamenjarin, I., Ugarković, M. (Eds), Exploring the Neighborhood. The Role of Ceramics in Understanding Place in the Hellenistic World, International Association for Research on Pottery of the Hellenistic Period 3, Wien, 343-352

Lipovac Vrkljan, G. 2011: Lokalna keramičarska radionica Seksta Metilija Maksima u Crikvenici - Crikveničke amfore ravnog dna / Local pottery workshop of Sextus Metilius Maximus in Crikvenica - Crikvenica flat-bottomed amphorae, [in:] Lipovac 
Vrkljan, G., Radić Rossi, I., Šiljeg, B. (Eds), Rimske keramičarske i staklarske radionice: proizvodnja i trgovina na Jadranskom prostoru: Zbornik 1. međunarodnog arheološkog kolokvija Crikvenica, 23.-24. listopada 2008, Cirkvenica, 3-18

Machut, P., Ben Amara, A., Cantin, N., Chapoulie, R., Frèrebeau, N., Le Bourdonnec, F.-X., Marion, Y., Tassaux, F. 2015: Towards high resolution ceramic series for production site studies: the case of Loron amphorae (Croatia, 1st-3rd c. A.D.), Heritage Science $3 / 21,1-7$

Manacorda, D., Pallecchi S. (Eds) 2012: Le fornaci romane di Giancola (Brindisi), BiArch 27, Bari

Maritan, L., Mazzoli, C., Mazzocchin, S. 2019: Provenance of wine and oil amphorae in northern Adriatic: archaeometric and epigraphic approaches, ArcheoSciences 43/2, 203-210

Menchelli, S., Pasquinucci, M., Pesavento Mattioli, S., Piazza, M. 2008: Anfore e laterizi adriatici: dati tipologici, epigrafici ed archeometrici a confronto, $R C R F 40,373-378$

Meyza, H. 2010: Under the shade of Aphrodite. Polish excavations in Paphos, Cyprus 2002-2009, Academia 2/26, 36-38

Meyza, H., Bagińska, D. 2013: Roman Amphorae from the Polish Excavations at Paphos, Maloutena: An Overview, [in:] Lawall, M.L., Lund, J. (Eds), The Transport Amphorae and Trade of Cyprus, Gösta Enbom Monographs 3, Aarhus, 133-153

Meyza, H., Romaniuk, M.M., Więch, M. with appendices by Mazanek-Somerlik, D., Więch, M. 2017: Nea Paphos. Seasons 2014 and 2016, PAM XXVI/1, 399-428

Panella, C. 2010: Roma, il suburbio e l'Italia in età medio- e tardo- repubblicana: cultura materiale, territori, economie, Facta 4, 11-123

Papuci-Władyka, E. 2020a: Interdisciplinary Research of the Jagiellonian University in Nea Paphos UNESCO World Heritage Site (2011-2015): First Results, Paphos Agora Project 1, Cracow

Papuci-Władyka, E. 2020b: Paphos Agora Project (PAP): its aims, stages of development, methodology and chronology, [in:] Papuci-Władyka, E. (Ed.), Interdisciplinary Research of the Jagiellonian University in Nea Paphos UNESCO World Heritage Site (2011-2015): First Results, Paphos Agora Project 1, Cracow, 73-89

Papuci-Władyka, E., Miszk, Ł. 2020: A Brief History of Research on Nea Paphos (without the Agora), [in:] Papuci-Władyka, E. (Ed.), Interdisciplinary Research of the Jagiellonian University in Nea Paphos UNESCO World Heritage Site (2011-2015): First Results, Paphos Agora Project 1, Cracow, 91-109

Peacock, D.P.S., Williams, D.F. 1986: Amphorae and the Roman economy: an introductory guide, London-New York

Pesavento Mattioli, S., Carre, M.-B. (Eds) 2009: Olio e pesce in epoca romana. Produzione e commercio nelle regioni dell'alto Adriatico. Atti del convegno (Padova, 16 febbraio 2007), Antenor Quaderni 15, Roma

Radić, I. 2003: The Adriatic Within the Mediterranean: Some Characteristic Shipwrecks from the Roman Period, [in:] Brebbia, C.A., Gambin, T. (Eds), Maritime Heritage, Advances in Architecture 15, Southampton, 155-165 
Romaniuk, M.M. 2017: A circular pool in the main courtyard of the "Hellenistic" House in Nea Paphos. Preliminary remarks, PAM XXVI/1, 429-440

Royal, J.G. 2012: Illyrian Coastal Exploration Program (2007-2009): The Roman and Late Roman Finds and Their Contexts, AJA 116/3, 405-460

Sondi, I., Slovenec, D. 2003: The Mineralogical Characteristics of the Lamboglia 2 Romanage Amphorae from the Central Adriatic (Croatia), Archaeometry 45/2, 251-262

Szakmány, G., Józsa, S. 2019: Micropetrography of the Fazana amphorae, [in:] Bezeczky, T. (Ed.), Amphora Research in Castrum Villa on Brijuni Island, ArchForsch 29, Wien, 187-196

Szakmány, G., Józsa, S., Bezeczky, T., Taubald, H. 2020: Fažana amphorae: geological context and new petrographic and chemical results, [in:] Machut, P., Marion, Y., Ben Amara, A., Tassaux, F. (Eds), Adriatlas 3. Recherches pluridisplinaires récentes sur les amphores nord-adriatiques à l'époque romaine, Bordeaux, 79-102

Sztetyłło, Z. 1991: Pottery stamps (1975-1989), Nea Paphos IV, Warsaw-Bielsko-Biała

Sztetyłło, Z. 2010: Nea Paphos VI. Pottery stamps from Nea Paphos (excavations in 1990-2006), PCMA Monograph Series 2, Warszawa

Toniolo, A. 1991: Le anfore di Altino, Padova

Toniolo, A. 2000: Le anfore di Adria: IV-II secolo a.C., Venezia

Vandermersch, Ch. 1994: Vins et amphores de Grande Grèce et de Sicile, IV ${ }^{\mathrm{e}}-\mathrm{III}^{\mathrm{e}}$ s. avant J.-C, Etudes 1, Naples

Zupančič, N., Horvat, J., Bole, M. 1998: The production of Greco-Italic amphorae in the Adriatic region, Materiali in geookolje 45/3-4, 345-357 

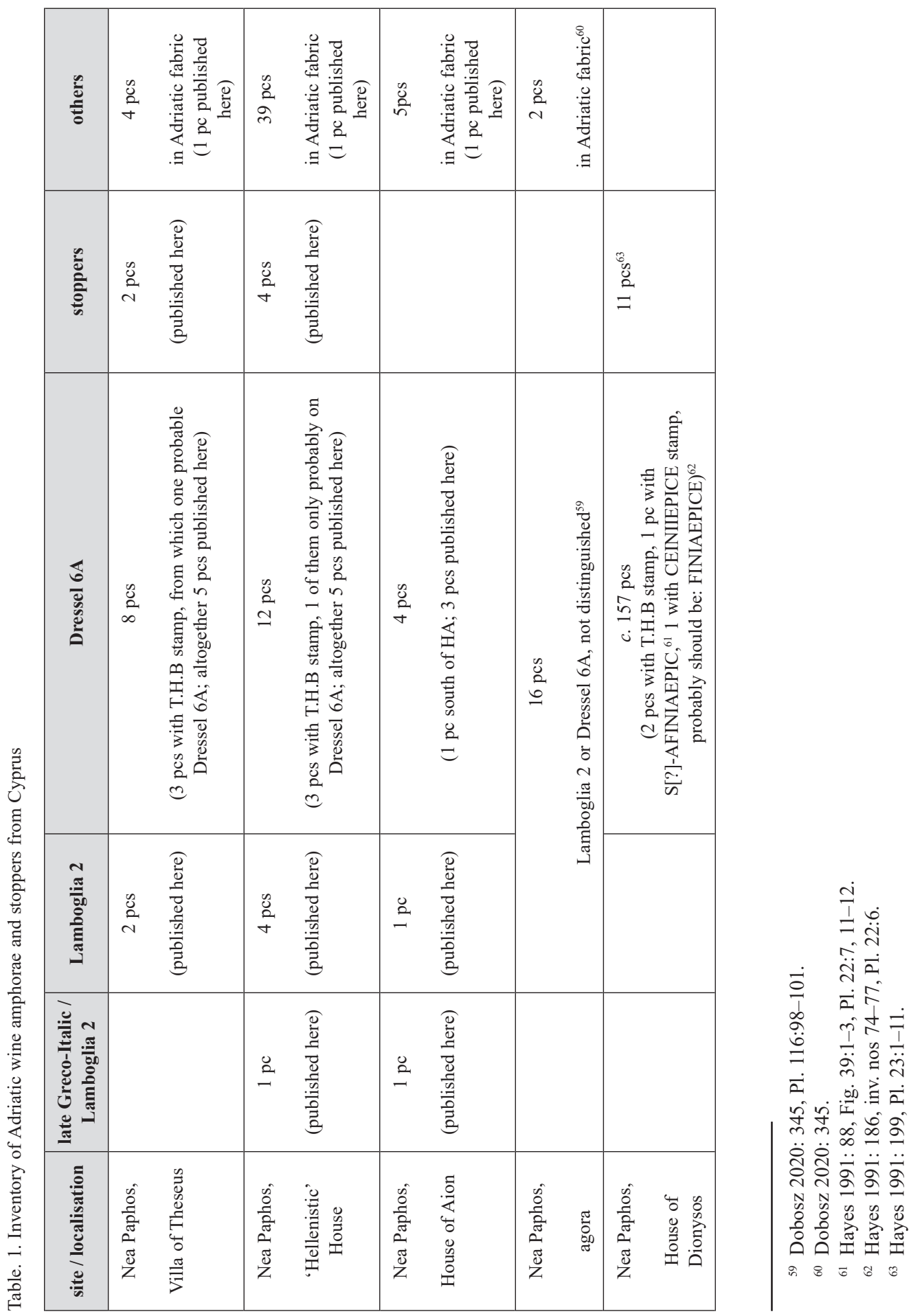


\begin{tabular}{|c|c|c|c|c|c|c|c|c|c|c|}
\hline 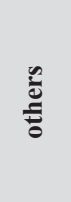 & 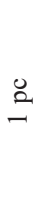 & 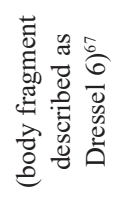 & & & $\frac{\tilde{z}}{\tilde{n}}$ & & & & \multicolumn{2}{|c|}{ 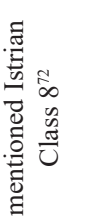 } \\
\hline$\frac{\tilde{b}}{\frac{n}{0}}$ & 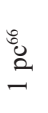 & & & & $\begin{array}{l}\tilde{\varrho} \\
\infty \\
\infty\end{array}$ & & & & & \\
\hline 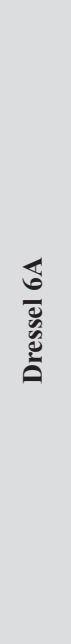 & $\begin{array}{c}\text { on } \\
c_{n}^{2}\end{array}$ & 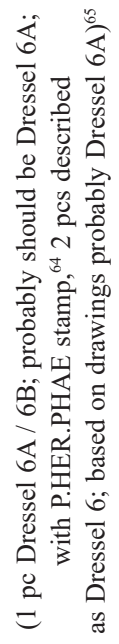 & 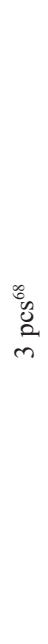 & 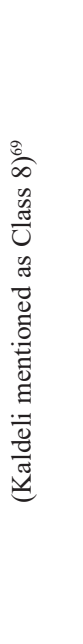 & 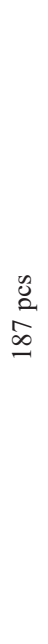 & $\begin{array}{l}\tilde{0} \\
0 \\
0 \\
0\end{array}$ & 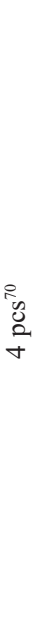 & 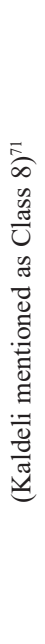 & & \\
\hline 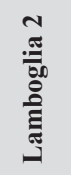 & & & & & 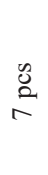 & & & & & \\
\hline 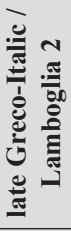 & & & & & $\begin{array}{c}\tilde{U} \\
\stackrel{0}{\alpha} \\
\sim\end{array}$ & & & & & \\
\hline 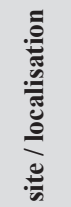 & 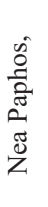 & 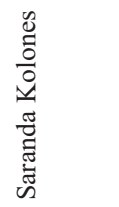 & 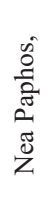 & 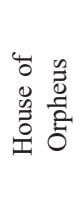 & 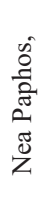 & 胥 & 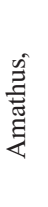 & 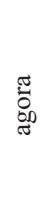 & 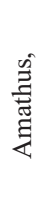 & 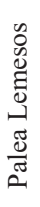 \\
\hline
\end{tabular}

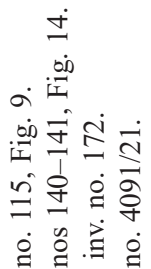

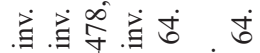

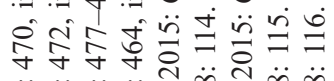

$\ddot{\sim} \ddot{\sim} \ddot{\sim} \ddot{\sim} \ddot{\infty} \sim \ddot{\infty} \ddot{\infty}$

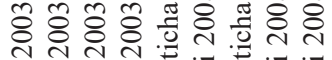

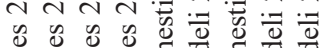

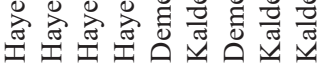

त 8 \& 8 \& 8 त 


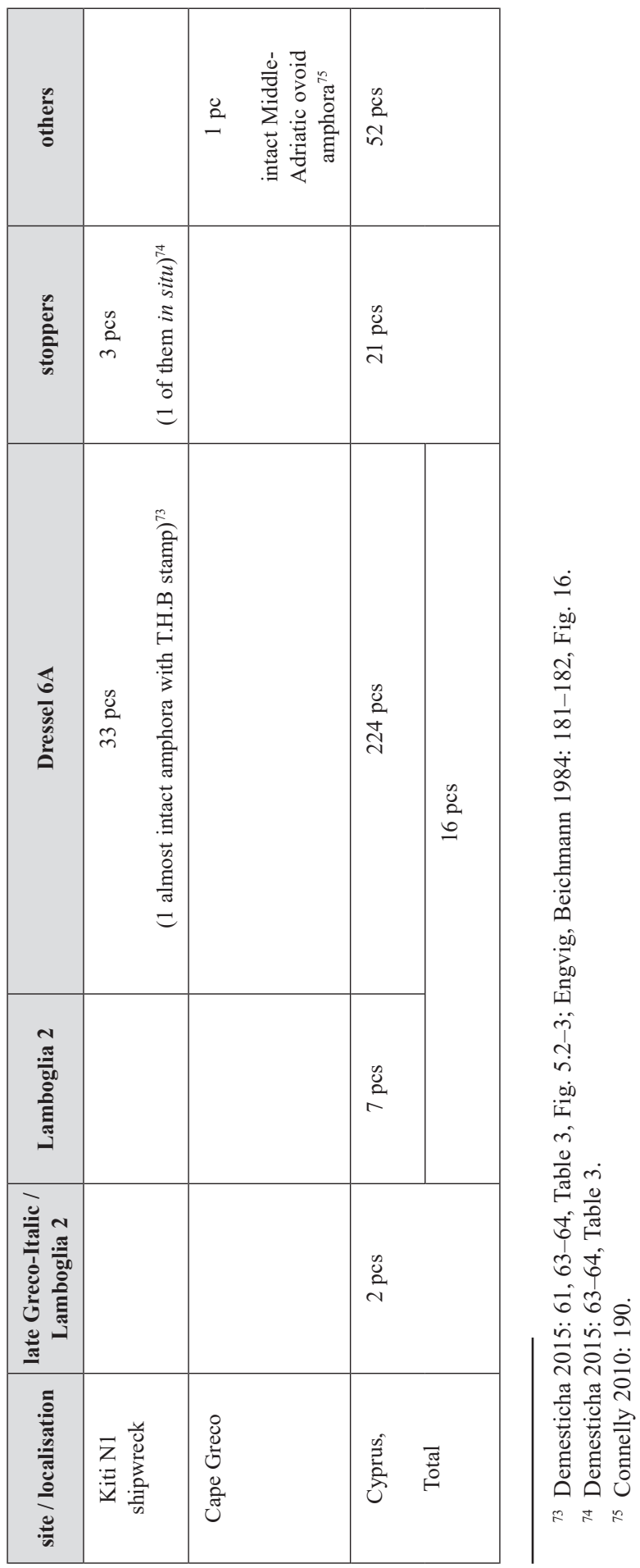





\section{CATALOGUE}

The catalogue presents only those fragments that preserved distinctive elements allowing for typological classification of the vessels or classification as stoppers. However, the gradual evolution of discussed wine amphorae, where one type developed from another, which is confirmed by the existence of transitional types, hampers typological classification of badly preserved fragments. Therefore, some specimens could represent one of the two following types. The inventory numbers given in the catalogue were introduced when particular pieces were included into database of Adriatic amphorae and stoppers. 
1. Greco-Italic MGS VI or early Lamboglia 2 amphora, rim fragment; inv. no. 48; context: the House of Aion (1990); fabric: visible inclusions - sand; colour: section pink (7.5YR 7/4), surface pale yellow (5Y 8/3) and very pale brown (10YR 7/4); dimensions: w. $10 \mathrm{~cm}$, h. $5.8 \mathrm{~cm}$, wall th. $1.4-1.6 \mathrm{~cm}$; date: second half of second century BC.

2. Greco-Italic MGS VI or early Lamboglia 2 amphora, rim fragment; inv. no. 58; context: the 'Hellenistic' House (1990); fabric: visible fine inclusions - sand and red-brown particles; colour: section and surface pale yellow (5Y 8/3); dimensions: w. $14.4 \mathrm{~cm}$, h. $6.3 \mathrm{~cm}$; date: second half of second century BC.

3. Lamboglia 2 amphora, rim and neck fragment; inv. no. 56; context: the Villa of Theseus (1987); fabric: visible red lumps as a part of matrix (terra rossa) and inclusions - silver mica, black and red-brown particles; colour: surface very pale brown (10YR 8/4), section reddish yellow (5YR 7/6); dimensions: w. $9.3 \mathrm{~cm}$, h. $9.3 \mathrm{~cm}$, rim th. $2.6 \mathrm{~cm}$, wall th. $1.6 \mathrm{~cm}$; date: second half of second century - late first century BC.

4. Lamboglia 2(?) amphora, rim fragment; inv. no. 51; context: the Villa of Theseus (1994); fabric: visible fine inclusions - silver mica, black and red-brown particles and sand; colour: section and surface pink and reddish (7.5YR 7/4 and 7/6); dimensions: w. $11.3 \mathrm{~cm}, \mathrm{~h} .5 .1 \mathrm{~cm}$; date: second half of second century - late first century $\mathrm{BC}(?)$.

5. Lamboglia 2 amphora, rim fragment; inv. no. 62; context: the 'Hellenistic' House (1987); fabric: visible red lumps as a part of matrix (terra rossa) and fine inclusions - sand, silver mica and red-brown particles; colour: reddish yellow (5YR 7/6); dimensions: w. $12.8 \mathrm{~cm}$, h. $6 \mathrm{~cm}$, rim th. $2.9 \mathrm{~cm}$; date: second half of second century - late first century BC.

6. Lamboglia 2(?) amphora, rim fragment; inv. no. 61; context: 'Hellenistic' House (1990); fabric: visible fine inclusions - red-brown and black particles, limestone; colour: section and surface reddish yellow section (7.5YR 6/6 - 7/6); dimensions: w. $7.7 \mathrm{~cm}$, h. $4.2 \mathrm{~cm}$, rim th. $2.1 \mathrm{~cm}$, wall th. $1.8 \mathrm{~cm}$; date: second half of second century - late first century $\mathrm{BC}(?)$.

7. Lamboglia 2 amphora, rim fragment; inv. no. 7; context: the 'Hellenistic' House (2016); fabric: visible red lumps as a part of matrix (terra rossa) and fine inclusions - black and red-brown particles, silver mica; colour: surface very pale brown (10YR 8/4), section very pale brown (10YR 7/4) and pink (7.5YR 7/4); dimensions: h. $3.9 \mathrm{~cm}$, wall th. $1.8 \mathrm{~cm}$; date: second half of second century - late first century BC. 

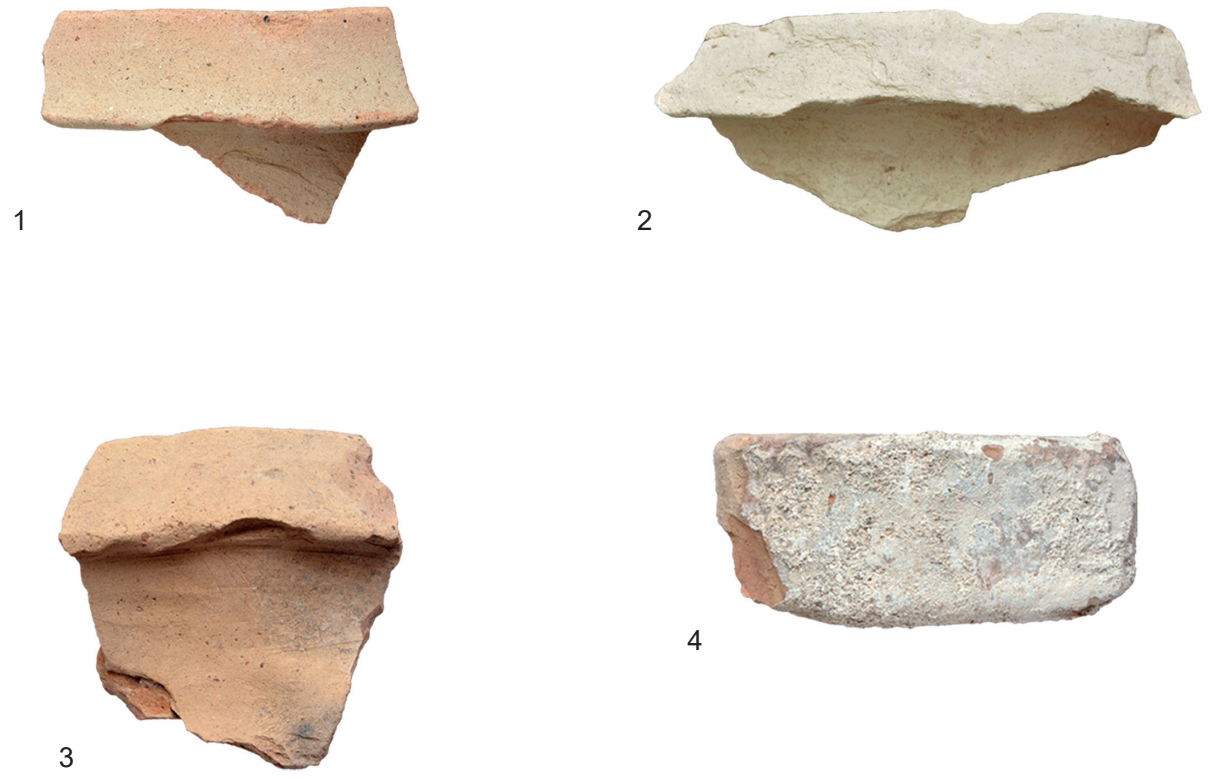

4
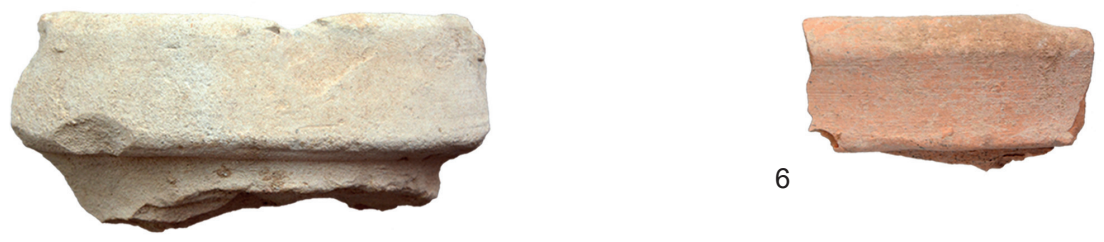

5
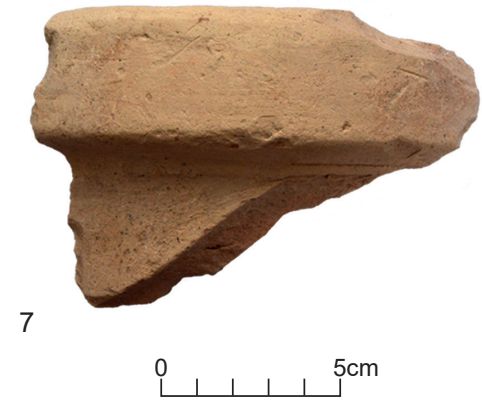

4. Adriatic wine amphorae from Nea Paphos, Maloutena: 1-2. Greco-Italic MGS VI or Lamboglia 2; 3-7. Lamboglia 2 (Phot. and processing: M. Bajtler). 
8. Lamboglia 2 amphora, handle and body fragment; inv. no. 19; context: the 'Hellenistic' House (2016); fabric: visible red lumps and smears as a part of matrix (terra rossa) and fine inclusions - limestone, silver mica, black and red-brown particles; colour: surface very pale brown (10YR 8/3), section reddish yellow (5YR 7/6), dimensions: handle cross-section $3.7 \times 2.9 \mathrm{~cm}$, wall th. $2.0 \mathrm{~cm}$; date: second half of second century - late first century BC.

9. Lamboglia 2 amphora, rim; inv. no. 49; context: the House of Aion (1990); fabric: visible red lumps and smears as a part of matrix (terra rossa) and fine inclusions - silver mica, limestone, black and red-brown particles; colour: section reddish yellow (5YR 6/6), surface reddish yellow (7.5YR 7/6); dimensions: rim d. $14.5 \mathrm{~cm}$, rim th. $1.9 \mathrm{~cm}$, neck d. $11 \mathrm{~cm}$, wall th. $1.5 \mathrm{~cm}$; date: second half of second century - late first century BC.

10. Dressel 6A amphora, rim fragment; inv. no. 6; context: the 'Hellenistic' House (2016); fabric: visible fine inclusions - red-brown and black particles, silver mica; colour: section and surface very pale brown (10YR 8/3); dimensions: d. $17.1 \mathrm{~cm}$, rim th. $3.2 \mathrm{~cm}$; date: late first century BC - mid first century AD; references: Meyza et al. 2017: 423, Fig. 24.3.

11. Dressel 6A amphora, handle fragment; inv. no. 41; context: the 'Hellenistic' House (2016); fabric: visible fine inclusions: red-brown and black particles, silver mica; colour: section and surface very pale brown (10YR $8 / 3)$; dimensions: d. $4.7 \mathrm{~cm}$; date: late first century $\mathrm{BC}-$ mid first century $\mathrm{AD}$.

12. Dressel 6A amphora, rim fragment, stamped with T.H.[B], T. H(elvi) B(asilae) (see Fig. 3); inv. no. 54; context: the Villa of Theseus (1985); fabric: visible fine inclusions - red-brown and black particles; colour: section very pale brown (10YR 7/4), surface pink (7.5YR 8/4); dimensions: w. $12.8 \mathrm{~cm}$, h. $4.4 \mathrm{~cm}$, rim th. $3.3 \mathrm{~cm}$; date: first half of first century AD; references: Sztetyło 1991: 101, no. 247.

13. Dressel 6A amphora, rim and handle fragment; inv. no. 63; context: the Villa of Theseus (1986); fabric: visible red lumps as a part of matrix (terra rossa) and inclusions - silver mica, black and red-brown particles; colour: section reddish yellow (5YR 7/6), surface very pale brown (10YR 7/4); dimensions: handle d. $5.2 \mathrm{~cm}$, rim th. $2.1 \mathrm{~cm}$, wall th. $1.5-2.1 \mathrm{~cm}$; date: late first century $\mathrm{BC}-$ mid first century AD.

14. Dressel 6A amphora, rim fragment; inv. no. 52; context: the Villa of Theseus (1994); fabric: visible fine inclusions - black and red-brown particles, silver mica; colour: surface and section pink (5YR 7/4); dimensions: w. $11.5 \mathrm{~cm}$, h. $7 \mathrm{~cm}$, rim th. $3.2 \mathrm{~cm}$; date: late first century $\mathrm{BC}-$ mid first century $\mathrm{AD}$. 

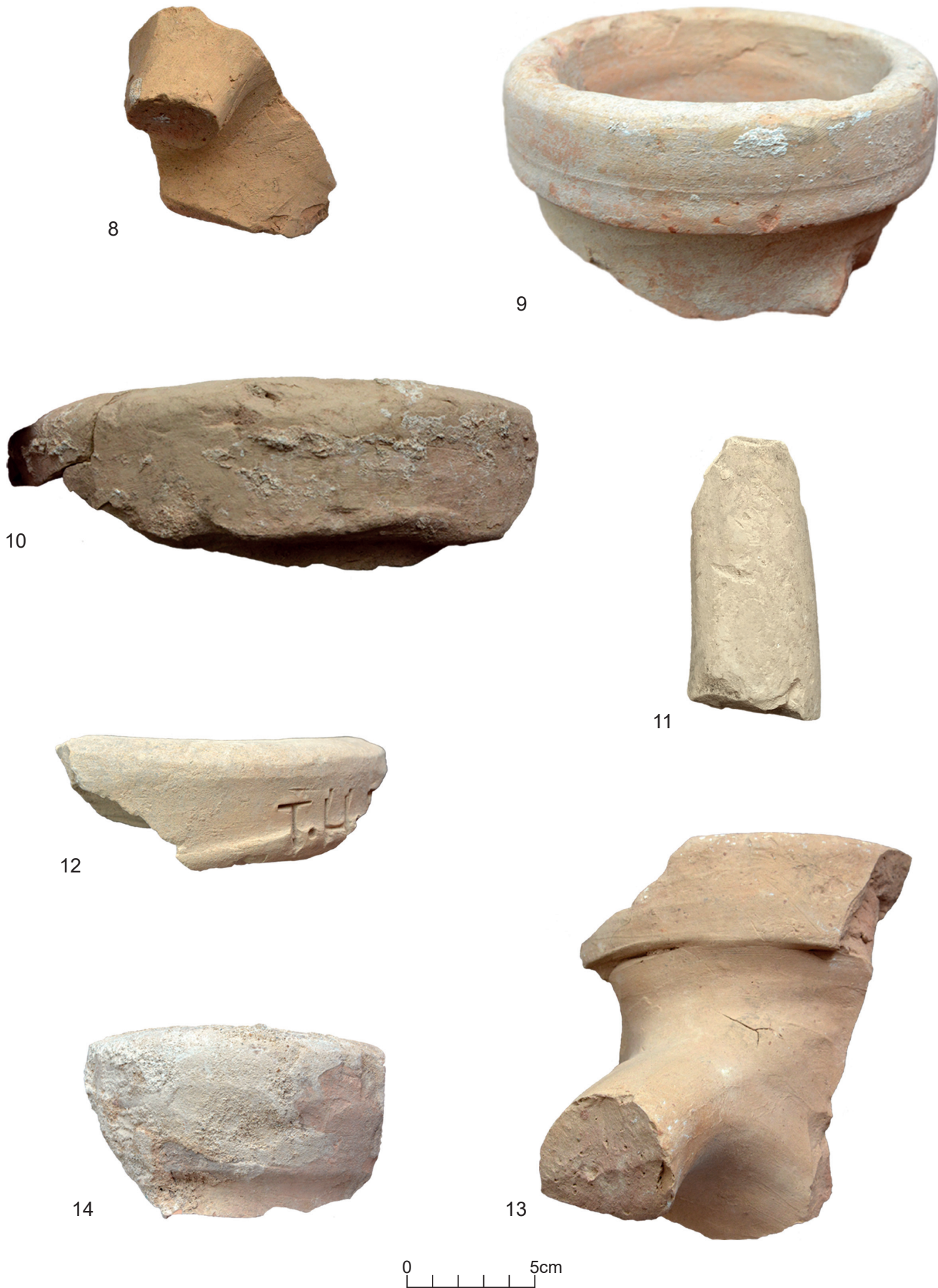

5. Adriatic wine amphorae from Nea Paphos, Maloutena: 8-9. Lamboglia 2;10-14. Dressel 6A (Phot. and processing: M. Bajtler). 
15. Dressel 6A amphora, foot; inv. no. 71; context: the Villa of Theseus (1995); fabric: visible red lumps as a part of matrix (terra rossa) and fine inclusions - black and red-brown particles; colour: section very pale brown (10YR 8/4); dimensions: h. $14 \mathrm{~cm}$; d. 3.8 and $6.3 \mathrm{~cm}$ (lowest and highest part respectively); date: late first century $\mathrm{BC}-$ mid first century AD.

16. Dressel 6A (small version?), rim with neck and handle fragment; inv. no. 77; context: the Villa of Theseus (1995); fabric: visible fine red lumps and smears as a part of matrix (terra rossa) and fine inclusions - silver mica, sand and red-brown particles; colour: section reddish yellow (7.5YR 6/6 and 5YR 6/6), surface pink (7.5YR 7/4); dimensions: h. $29 \mathrm{~cm}$, rim d. $12-14.3 \mathrm{~cm}$, rim th. $2.7 \mathrm{~cm}$, wall th. $2.5 \mathrm{~cm}$, handle d. $3.7 \mathrm{~cm}$; date: late first century $\mathrm{BC}-$ mid first century $\mathrm{AD}$.

17. Dressel 6A amphora, rim fragment; inv. no. 50; context: the 'Hellenistic' House (1994); fabric: visible fine inclusions - black and red-brown particles; colour: surface and section very pale brown (10YR 8/3); dimensions: h. $12 \mathrm{~cm}$, w. $11.3 \mathrm{~cm}$, rim th. $3 \mathrm{~cm}$, wall th. $1.5 \mathrm{~cm}$; date: late first century $\mathrm{BC}-$ mid first century AD.

18. Dressel 6A amphora, rim; inv. no. 8; context: the 'Hellenistic' House (2016); fabric: visible red lumps as a part of matrix (terra rossa) and inclusions - silver mica, black and red-brown particles; colour: surface and section very pale brown (10YR 8/3 and 8/4); dimensions: d. $17.5 \mathrm{~cm}$, wall th. $2.1 \mathrm{~cm}$, rim th. $3.1 \mathrm{~cm}$; date: late first century $\mathrm{BC}-\operatorname{mid}$ first century AD; references: Meyza et al. 2017: 423, Fig. 24.1.

19. Dressel 6A amphora, body and handle fragment; inv. no. 37; context: the 'Hellenistic' House (2016); fabric: visible fine inclusions - silver mica, black and red-brown particles; colour: section pink (7,5YR 8/4), surface very pale brown (10YR 8/3); dimensions: w. $10.5 \mathrm{~cm}$, h. $7.4 \mathrm{~cm}$, wall th. $1.9 \mathrm{~cm}$, handle d. $4.3 \mathrm{~cm}$; date: late first century BC - mid first century AD. 


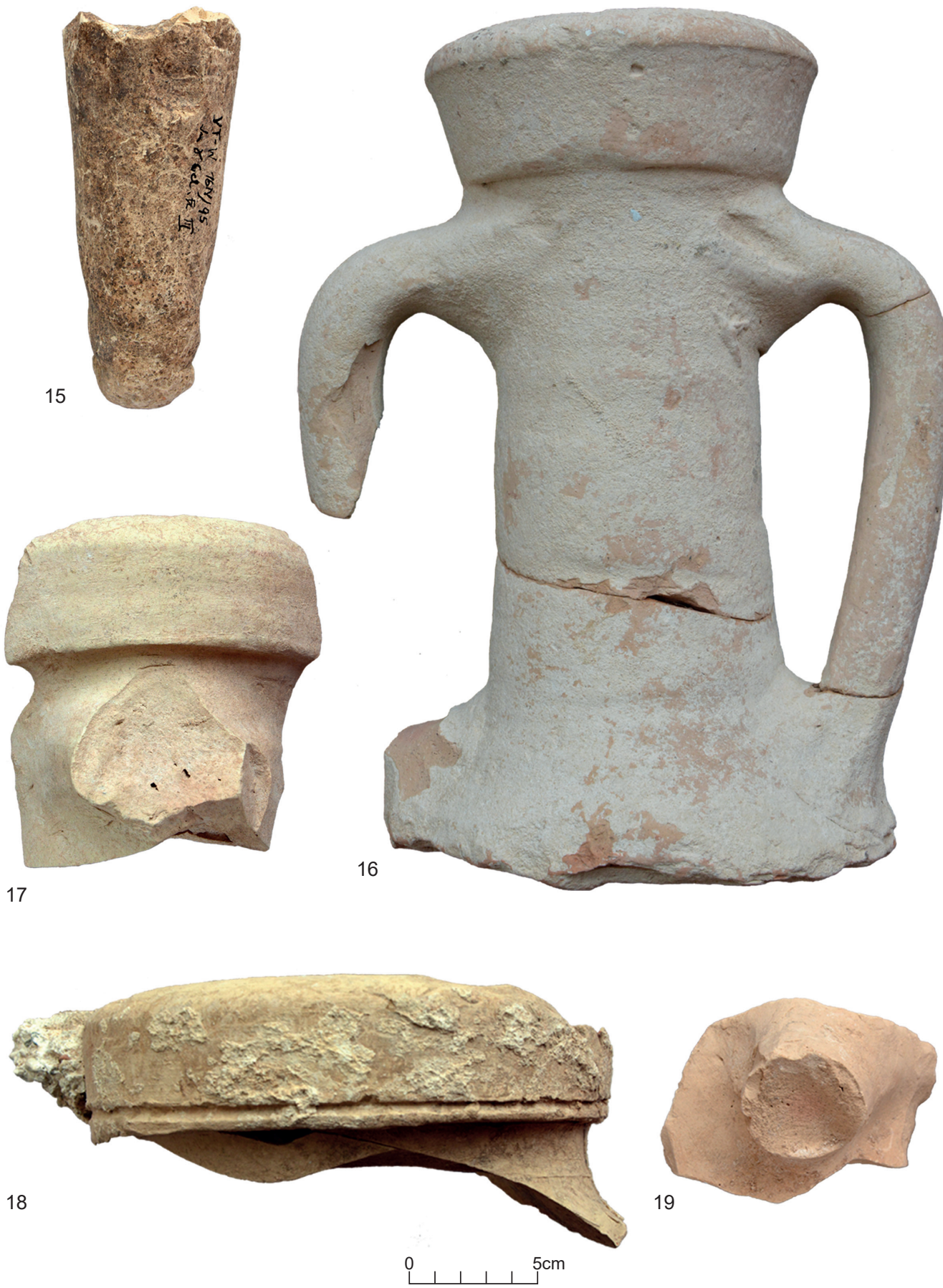

6. Adriatic wine amphorae from Nea Paphos, Maloutena: 15-19. Dressel 6A (Phot. and processing: M. Bajtler). 
20. Dressel 6A amphora, rim fragment; inv. no. 55; context: the House of Aion (1990); fabric: visible fine inclusions - sand, black and red-brown particles; colour: surface and section very pale brown (10YR $7 / 4$ and $8 / 4$ ); dimensions: h. $10 \mathrm{~cm}$, w. $7.5 \mathrm{~cm}$, rim th. $3.5 \mathrm{~cm}$, wall th. $1.8 \mathrm{~cm}$; date: late first century $\mathrm{BC}-$ mid first century $\mathrm{AD}$.

21. Dressel 6A amphora, handle fragment; inv. no. 66; context: the House of Aion (1990); fabric: visible fine inclusions - black and red-brown particles, silver mica; colour: surface and section very pale brown (10YR 8/3); dimensions: h. $8.7 \mathrm{~cm}$, d. $5.1 \mathrm{~cm}$; date: late first century $\mathrm{BC}-$ mid first century $\mathrm{AD}$.

22. Dressel 6A amphora, foot; inv. no. 70; context: the House of Aion (1990); fabric: visible fine inclusions: silver mica, black and red-brown particles; colour: section very pale brown (10YR 7/4), surface pink (7.5YR 8/4); dimensions: d. 4.0 and $7.3 \mathrm{~cm}$ (lowest and highest part respectively), h. $24.5 \mathrm{~cm}$; date: late first century BC - mid first century AD.

23. Stopper, intact; inv. no. 47; context: the Villa of Theseus (1994); fabric: visible inclusions - sand, black particles; colour: surface white and pale yellow $(2.5 \mathrm{Y} 8 / 2$ and $8 / 3$ ); dimensions: d. $9.3 \mathrm{~cm}$, th. $2.5 \mathrm{~cm}$.

24. Stopper, intact, decoration consisting of four lines radiating at regular intervals from the knob; inv. no. 1; context: the Villa of Theseus (1995); fabric: visible inclusions - sand, limestone, black particles; colour: surface very pale brown (10YR 8/3); dimensions: d. $9.5 \mathrm{~cm}$, th. $1.9-2.3 \mathrm{~cm}$.

25. Stopper, fragment; inv. no. 2; context: the 'Hellenistic' House (1989); fabric: visible red smears as a part of matrix (terra rossa) and fine inclusions: silver mica and black particles; colour: section white ( 5 Y $8 / 2$ ), surface light gray ( $5 \mathrm{Y} 7 / 2)$, possibly overfired; dimensions: $\mathrm{d} .8 .8 \mathrm{~cm}$, th. $1.6 \mathrm{~cm}$.

26. Stopper, fragment; inv. no. 3; context: the 'Hellenistic' House (1991); fabric: visible pale red smears as a part of matrix (terra rossa) and inclusions - black and red-brown particles, silver mica, limestone; colour: surface and section very pale brown (10YR 8/3); dimensions: d. c. $9.1 \mathrm{~cm}$, th. $2.3 \mathrm{~cm}$.

27. Stopper, fragment; inv. no. 5; context: the 'Hellenistic' House (1995); fabric: visible dark red smears as a part of matrix (terra rossa) and inclusions: silver mica, black and red-brown particles; colour: section very pale brown (10YR 7/4); dimensions: d. c. $8.6 \mathrm{~cm}$, th. $2.0 \mathrm{~cm}$. 

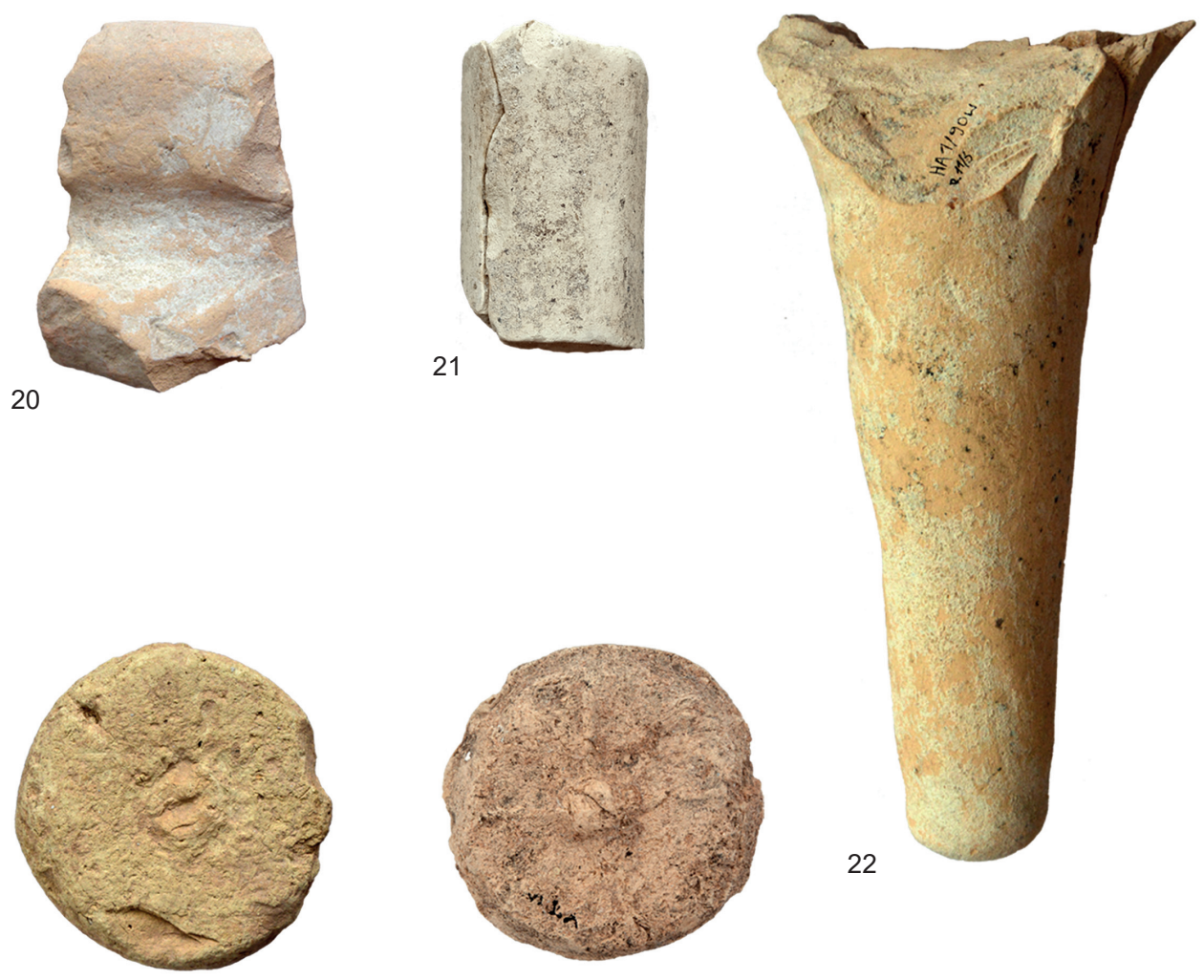

22

24

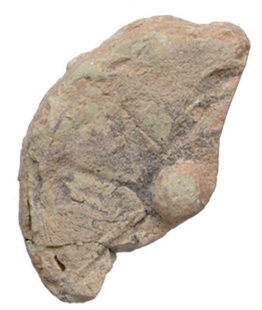

25
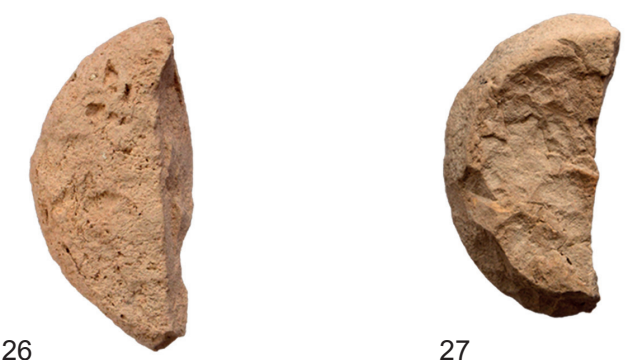

27

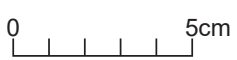

7. Adriatic amphorae and stoppers from Nea Paphos, Maloutena: 20-22. Dressel 6A; 23-27. stoppers (Phot. and processing: M. Bajtler). 
28. Stopper, intact; inv. no. 23; context: the 'Hellenistic' House (2016); fabric: visible red lumps and smears as a part of matrix (terra rossa) and inclusions - sand, black and red-brown particles; colour: section pink (5YR $8 / 3)$, surface white $(2,5 \mathrm{Y} 8 / 2)$, possibly overfired; dimensions: d. 8.8-9.7cm (irregular shape), th. 1.7-2.1cm; references: Meyza et al. 2017: 423, Fig. 24.2 .

29. Adriatic amphora, handle fragment; inv. no. 67; context: the House of Aion (1990); fabric: visible inclusions - sand, black and red-brown particles; colour: section pink (5YR 8/4), surface very pale brown (10YR 8/3); dimensions: h. $6.0 \mathrm{~cm}$; d. $4.7 \mathrm{~cm}$.

30. Adriatic amphora, handle fragment; inv. no. 18; context: the 'Hellenistic' House (2016); fabric: visible fine inclusions - black and red-brown particles; colour: section pale yellow (5Y 8/4), surface pale yellow (2.5Y 8/4); dimensions: cross-section $3.4 \times 4.9 \mathrm{~cm}$.

31 Adriatic amphora, handle and body fragment; inv. no. 65; context: the Villa of Theseus (1988); fabric: visible fine inclusions - silver mica, black and red-brown particles; colour: surface and section reddish yellow (7.5YR 7/6); dimensions: h. $9.3 \mathrm{~cm}$, w. $8.7 \mathrm{~cm}$, wall th. $1.8 \mathrm{~cm}$, handle cross-section $3.7 \times 4.6 \mathrm{~cm}$. 

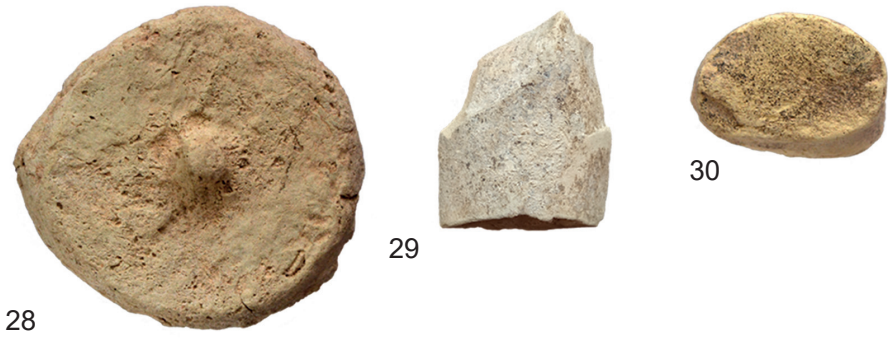

30

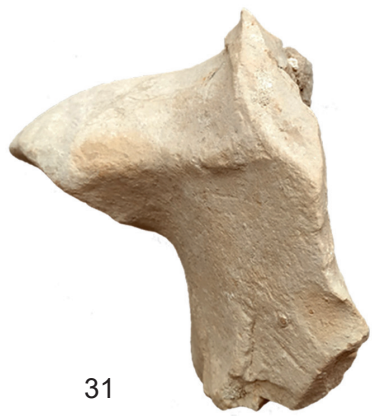

8. Adriatic amphorae and stoppers from Nea Paphos, Maloutena: 28. stopper; 29-31. typologically unclassified fragments of Adriatic amphorae (Phot. and processing: M. Bajtler). 


\section{ÉTUDES et TRAVAUX XXXIV / 2021}
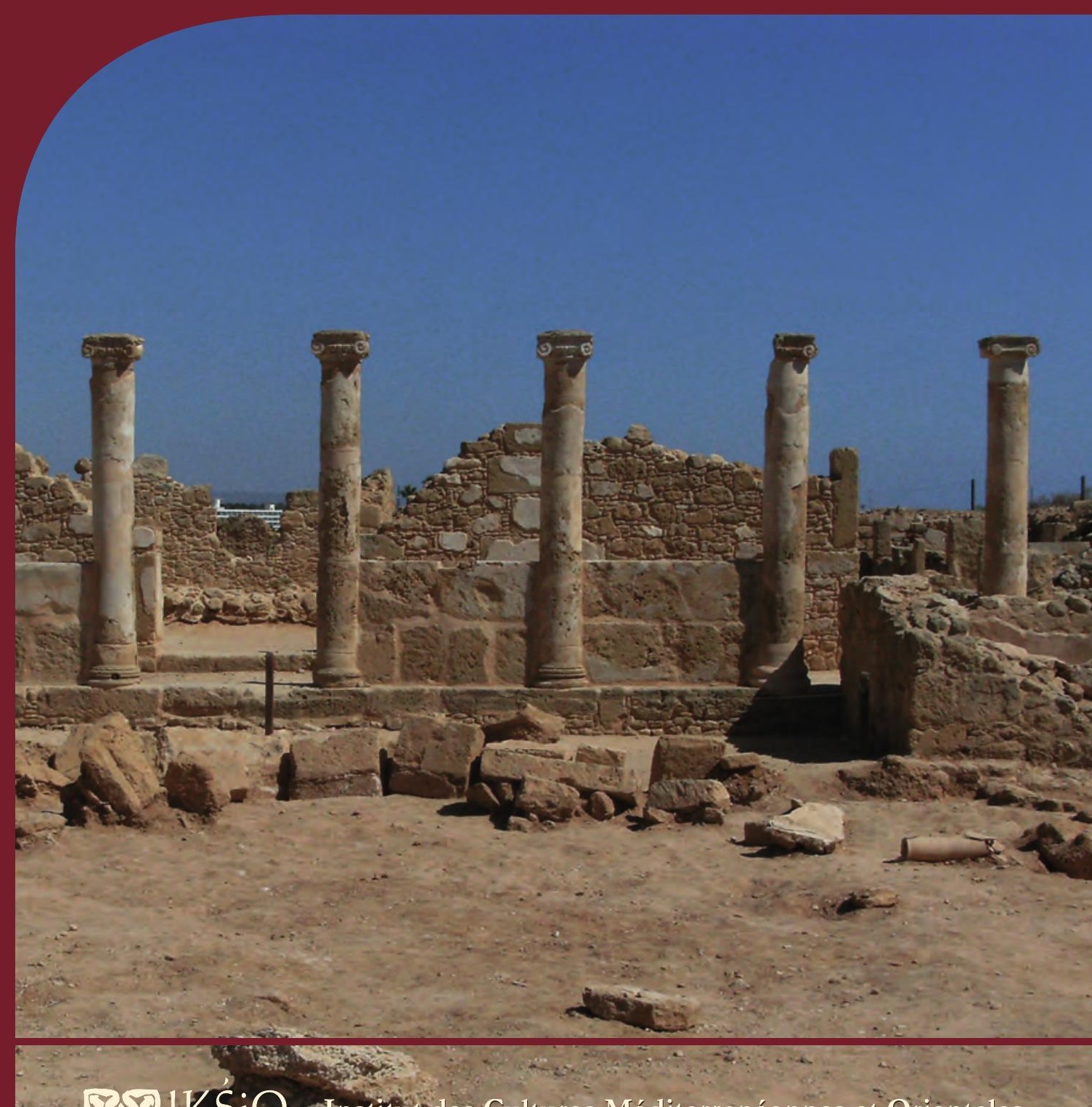

W $92 \mathrm{HKSiO}$ Institut des Cultures Méditerranéennes et Orientales

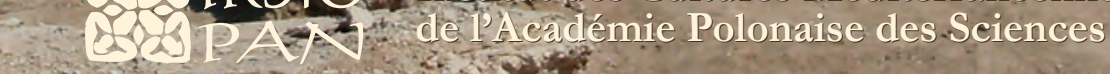

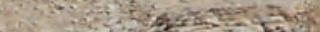

Q 
COMITÉ DE RÉDACTION SCIENTIFIQUE

Maciej Makowski - rédacteur en chef

Jadwiga Iwaszczuk - rédacteur

Katarzyna Kapiec - secrétaire de la rédaction

Henryk Meyza - rédacteur thématique du volume

CONSEIL SCIENTIFIQUE DU JOURNAL

M. Kobusiewicz (IAE PAN, Warszawa)

E. Laskowska-Kusztal (IMOC PAS, Warszawa)

D. Michaelides (University of Cyprus, Nicosia)

J.Ch. Moretti (IRAA-MOM, Université de Lyon 2/CNRS)

D. Raue (Ägyptisches Museum der Universität Leipzig)

P. Reynolds (ICREA, España)

D. Welsby (British Museum, London)

COMITÉ SCIENTIFIQUE DE LECTURE

la liste des membres du comité est accessible en ligne sur

http://www.etudesettravaux.iksiopan.pl

RÉDACTION TECHNIQUE

Marta Kaczanowicz

REVUE DES TEXTES EN ANGLAIS

Jo Harper 
ÉTUDES et TRAVAUX XXXIV 
INSTYTUT KULTUR ŚRÓDZIEMNOMORSKICH I ORIENTALNYCH POLSKIEJ AKADEMII NAUK

\title{
STUDIA i PRACE
}

\section{XXXIV}

\author{
GoIKSiO \\ QSO PAN \\ WARSZAWA \\ 2021
}


INSTITUT DES CULTURES MÉDITERRANÉENNES ET ORIENTALES DE L’ACADÉMIE POLONAISE DES SCIENCES

\section{ÉTUDES et TRAVAUX}

XXXIV

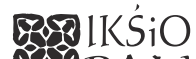

EOSPAN

VARSOVIE

2021 
Publication scientifique financée dans le cadre du programme du Ministre de la Science et de l’Éducation Supérieure

« Programme National de Développement de l’Humanistique » pour les années 2016-2021 (projet no 3bH 150099 83)

\title{
(1) NARODOWY PROGRAM ROZWOJU HUMANISTYKI
}

\author{
Copyright $(C)$ \\ Instytut Kultur Śródziemnomorskich i Orientalnych PAN \\ et les Auteurs \\ Warszawa 2021
}

ISSN 2084-6762

(jusqu'en 2011 : 0079-3566)

e-ISSN 2449-9579
Version première en papier, imprimée en Pologne - 150 copies
Version électronique accessible sur
http://www.etudesettravaux.iksiopan.pl

Édition: Polskie Towarzystwo Historyczne et Wydawnictwo Neriton, Warszawa

Conception générale de la couverture : J. Iwaszczuk

Photographie de couverture : Phot. A. Brzozowska-Jawornicka

(Le portique ionique est, péristyle de la Maison « hellénistique », Nea Paphos) 


\section{Table des matières}

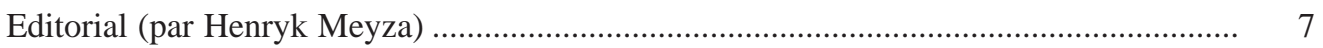

Marta BaJTLER

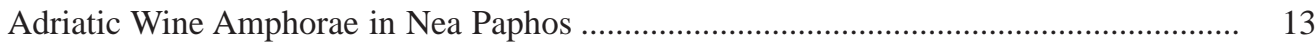

Claire Balandier, Jolanta MlynarczyK

The Temple and Its Surroundings on Fabrika Hill, Paphos: Preliminary Results

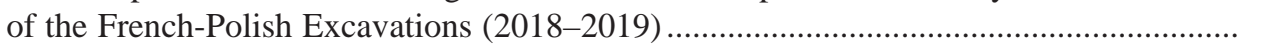

Grażyna BĄKowska-Czerner, Rafal CzERner

The Shell Motif in the Culture and Architecture of the Ancient Town of Marina el-Alamein in Egyp

AleKsandra BrzozowsKa-JaWornicKa

'Hellenistic' House in Nea Paphos, Cyprus - A First Summary of Its Architecture.

AleKsandra BrzozowsKa-JaWORnicKA, AnNa KuBICKA-SowińsKa

In Search of the Module in the Architectural Design of the 'Hellenistic'

House in Nea Paphos, Cyprus

RoKsana HaJduga

Kushite Stamp Impressions from Selib 2, Sudan

ERSIN HusSEIN

Mapping Metal Rich Roman Cyprus: The Case for Object-Centred Approaches

BARBARA LICHOCKA

Villa of Theseus at Nea Paphos (Cyprus). Fourth-Early Fifth Century Numismatic

Evidence for Architectural Transformations and Seismic Events

VASiliki Lysandrou, Demetrios Michaelides

Wall Paintings in Ancient Cyprus: The Hellenistic and Roman Tombs of Paphos

and Its Region

ADAM ŁAJTAR

A Weight of Seleucia in Pieria in Nea Paphos

Diana MroczeK

Ancient Portrait Busts of Marcus Aurelius in the National Museum in Poznań 
Brandon R. Olson, R. Scott Moore, Thomas Landvatter, Justin Stephens

Pyla-Vigla: A Case Study Assessing the Imperial Strategies of the Hellenistic

Diadochoi in Cyprus

Patrizio Pensabene, Eleonora Gasparini

Colonnaded Hall in Kourion: How the Oecus Corinthius Was Interpreted in the Roman

Houses of Cyprus

Monika Rekowska, Demetrios Michaelides, Skevi Christodoulou, JAKUB KANISZEWSKI

Adopting Roman Habits - The Baths in the House of Orpheus in Nea Paphos

as a 'Troublesome' Case Study?

MARCIN M. ROMANIUK

Terracotta Pipelines at Maloutena: Remarks on the Water System in the

Residential District of Ancient Nea Paphos, Cyprus

363

ABRÉVIATIONS

407 